\title{
REEVALUATING THE EVIDENCE FOR MIDDLE WOODLAND MAIZE FROM THE HOLDING SITE
}

\author{
Mary L. Simon
}

\begin{abstract}
Maize fragments recovered from the Middle Woodland Holding site (11MS118) in the American Bottom have for several decades been recognized as the oldest directly dated maize east of the Mississippi River. A reevaluation of maize samples from this site indicates that finding was in error. Carbon isotope assessment ( $\delta^{13} C$ ratios) run on the original samples dated in 1994 indicated that they were not maize. Six additional samples originally identified as maize were submitted to the Illinois State Geological Survey for carbon ratio assessment and direct accelerated mass spectrometry dating. Three of the fragments, including one from the same feature dated previously, returned non-maize $\delta^{13} \mathrm{C}$ ratios. The other three samples were correctly identified as maize, but all returned post-A.D. 900 dates. These results invalidate the original report of Middle Woodland maize at Holding and support our ongoing reevaluations of maize histories in the American Bottom and western Illinois, which show that it was not an important cultivated crop plant in this part of the Midwest until about A.D. 900.
\end{abstract}

Los fragmentos de maíz recuperados en el sitio Holding (11MS118) del Periodo Middle Woodland en el "American Bottom" han sido reconocidos durante décadas como el maíz directamente datado más antiguo al este del río Mississippi. Una reevaluación de la muestra del maíz de este lugar indica que este hallazgo no fue acertado. Análisis de isótopos de carbono (índice de $\delta^{13}$ C) llevados a cabo en las muestras originales fechadas en el año 1994 señalaron que no eran maíz. Seis muestras adicionales de Holding identificadas en principio como maíz fueron enviadas al Instituto Geológico del estado de Illinois para analizar su índice de carbono y ordenar el fechado por masa espectrométrica acelerada. Tres de los fragmentos, incluyendo uno del mismo rasgo fechado anteriormente, devolvió índices de $\delta^{13} \mathrm{C}$ distintos a los del maíz. Las otras tres muestras fueron correctamente identificadas como maíz, pero todas arrojaron fechas posteriores al 900 d.C. Estos resultados anulan el informe original del maíz durante el periodo Middle Woodland en Holding y respaldan nuestras reevaluaciones en curso sobre la historia del maíz en el "American Bottom" y al oeste de Illinois, que muestra que no era una planta de cultivo en esta parte del Medio Oeste hasta 900 d.C.

$\mathrm{F}$ or over two decades, maize recovered from the Holding site (11MS118), located in the American Bottom region of Illinois (Figure 1), has appeared to stand as a testament to the antiquity of maize cultivation in the Eastern Woodlands. This extensive Middle Woodland occupation is the type site for the Hopewell-related Holding phase that Fortier et al. (1989:558-559) place between 50 B.C. and A.D. 150. Designation is based both on standard dates obtained on charcoal, which range in age between about $150 \mathrm{cal} \mathrm{B.C}$. and cal A.D. 300 (Fortier et al. 1989:Table 9) and have a median probability average date of A.D. 141 (dates from Fortier et al. [1989] recalibrated using Calib 7.1 [Stuiver and Reimer 2016]), and on the distinctive material culture (Fortier et al. 1989). The archaeobotanical assemblage included 18 small fragments variously identified as maize kernels, cobs, or cupules from six different features and the midden unit (Parker 1989; Riley et al. 1994:Table 1). Two of the alleged fragments, one identified as a kernel and one identified as a cob, were directly AMS-dated and returned dates of $2107 \pm 50$ RCYBP (AA8718 ) and $2077 \pm 70$ RCYBP (AA-8717) (Riley et al. 1994:493-494). Using Calib 7.1 (2016), these dates calibrate to 165 cal B.C.-A.D. 75 (2 sigma, $p=1.0$ ) and 233 cal B.C.-A.D. 68 (2 sigma, $p=.91$ ), respectively, placing them

Mary L. Simon — Illinois State Archaeological Survey, 209 Nuclear Physics, 23 Stadium Drive, Champaign, IL 61820 (msimon1@illinois.edu) 


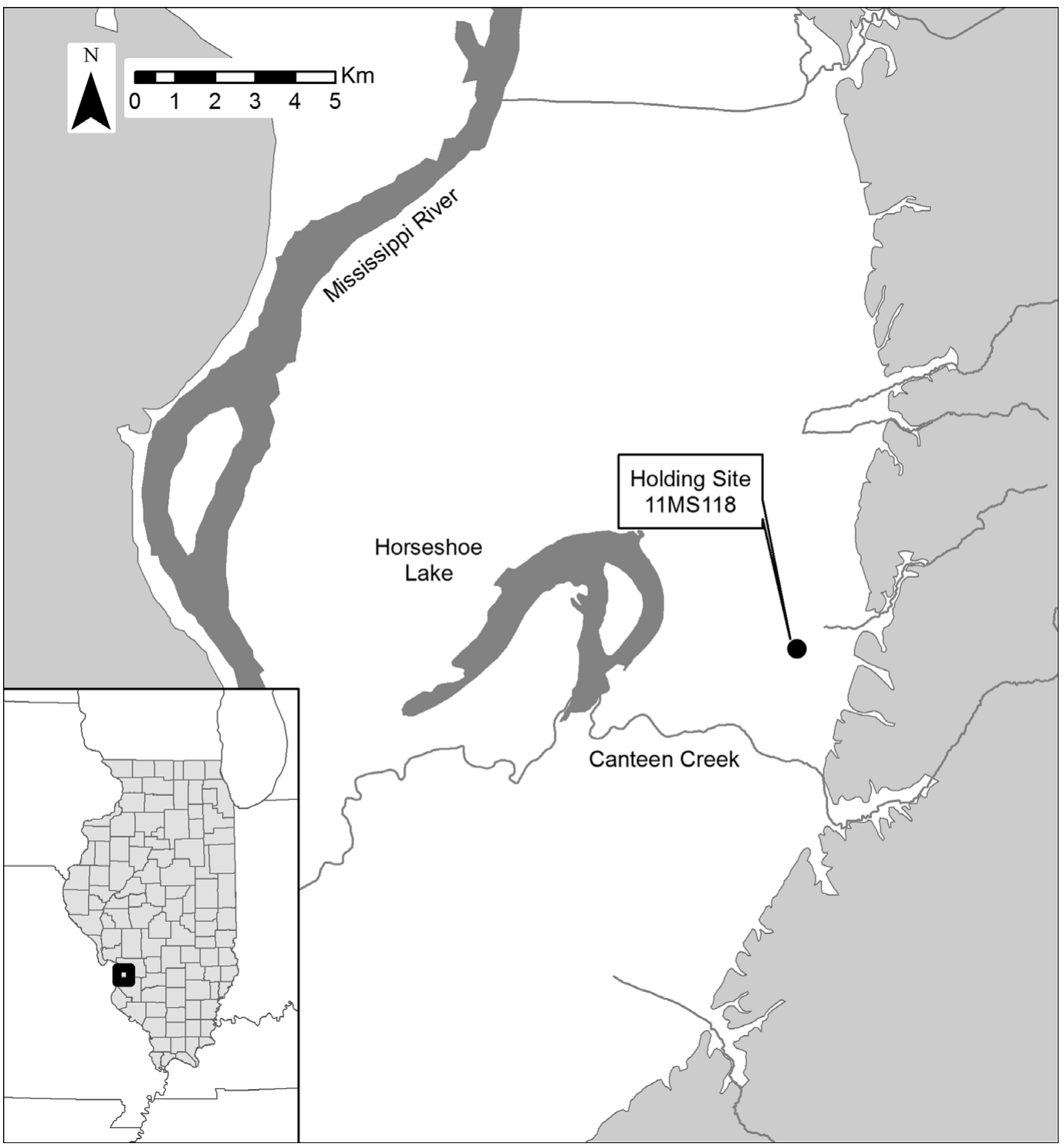

Figure 1. Location of the Holding site in the American Bottom region of Illinois.

well within the date range defined for the Holding phase (Parker 1989; Riley et al. 1994). As such, they have long been considered the oldest directly dated maize in the Eastern Woodlands of North America. Further, given their geographic location, they were ideally situated to provide a temporally credible geographic intermediary between the greater Eastern Woodlands as a whole and the southwestern United States.

Along with a few other alleged early dates on maize (Table 1), these finds have had a subtle but pervasive impact on our interpretations of maize history, both in the interior Midwest-here defined as those regions directly drained by the Mississippi River and its major tributaries, the Ohio River, the Illinois River, and the Missouri River-and farther afield in the greater Eastern Woodlands of North America. It is true that researchers working with collections from the interior Midwest have long suggested that maize did not contribute substantially to the diet of prehistoric peoples of that region until about A.D. 800 to 900 (Asch and Asch 1985; Fritz 1992, 2000; Johannessen 1993; Lopinot 1994, 
1997; Smith and Cowan 2003; VanDerwarker et al. 2013; Wright and Shaffer 2014; Wymer 1993). However, it is also true that, whether overtly noted or more indirectly assumed, the few reported middle and early Late Woodland macrobotanical records have been interpreted not only as evidence for the occasional presence of maize at an early date but also as evidence for its use as a "minor crop" during the centuries prior to its appearance as a major subsistence resource. In Illinois, this subtle conceptualization of maize as an integral, if minor, part of the cropping system during the first centuries A.D. was the basis for the gradualist model of maize use, which posited that low-level maize cultivation was initiated by about cal A.D. 100 and that large-scale cultivation was in place by cal A.D. 900 (e.g., Hastorf and Johannessen 1994; Lopinot 1994, 1997; Simon and Parker 2006; Wagner 1994). Further, this idea that the Holding site maize, along with the few other Middle Woodland macrobotanical records, were "early entries" in a long, gradual process has influenced models for maize use farther afield, including contentions that maize cultivation was widespread in the eastern Great Lakes regions of eastern Michigan, Ontario, and New York State by A.D. 700 (e.g., Boyd and Surette 2010; Boyd et al. 2008:2250; Crawford et al. 2006; Hart and Lovis 2013; Raviele 2010).

Results from recent work with archaeobotanical maize collections in Illinois call into question even the model of "minor maize cropping" among groups living in western Illinois and the American Bottom region prior to circa A.D. 900 (Emerson et al. 2015; Simon 2014). To date, 12 previously published records for preA.D. 900 maize in Illinois have been discredited and only one, that from the Edgar Hoener site $(1350 \pm 20$ RCYBP, cal A.D. 647-684, $p=$ 1.0 [ISGS A2242]; $\delta^{13} \mathrm{C}=-10.3 \%$ ), has been substantiated (Simon 2014:Table 3). In addition, while isotope values validate most original maize identifications, for two samples those original identifications were incorrect, returning $\delta^{13} \mathrm{C}$ values of $-25.1 \%$ and $-26.4 \%$ (Simon 2014:Table $3)$.

That research prompted the reevaluation of maize from the Holding site. Carbon isotope assessment $\left(\delta^{13} \mathrm{C}\right)$ was conducted on the original
1994 samples and on six additional samples to verify if they were maize. If determined to be maize, they were selected for direct dating using AMS. The results of this work call into question any claims for pre-A.D. 900 maize from western Illinois, including for the Holding site.

\section{Methods and Results}

The Holding site macrobotanical samples are curated at the Illinois State Archaeological Survey, Prairie Research Institute, at the University of Illinois Champaign-Urbana. They had been stored, as is standard practice, in plastic vials placed in curation-grade cardboard boxes. Other than small paper tags, there are no associated organic materials, and there is no reason to suspect that contamination is an issue.

The 18 items originally identified as maize were collected from five different features and from the extensive Middle Woodland midden present at the site (Riley et al. 1994:Table 1). Sixteen of the fragments remained. All were examined under low magnification $(\sim 8 \mathrm{x}$ to $60 \mathrm{x})$ using a stereoscopic microscope to evaluate condition and, to the extent possible, verify original identifications. This proved difficult, as most of the fragments lacked clearly distinguishing anatomical features. Consequently, sample selection was based on overall size, context of recovery, characteristic texture, and gross "form." Size was an important criterion as even AMS dating requires a minimum weight of about 20 milligrams and the fragments were quite small. Six fragments - three that were originally identified as kernel fragments, two that were originally identified as cupule fragments, and one that was originally identified as a cob fragmentwere selected for $\delta^{13} \mathrm{C}$ assessment and direct AMS dating. All the "kernel" fragments tended to exhibit the glossy, porous interior structure characteristic of carbonized, fragmented maize kernels as well as what appeared to be bits of the leathery adherent pericarp. The cupule fragment from Feature 159 retained evidence for the original kernel "boat"; that from Feature 5 was a large piece of porous tissue that was cupule-like only in terms of texture.

The materials identified as "cobs" in the original report were even more problematic. 
Table 1. Early Direct Dates on Maize from the Eastern United States.

\begin{tabular}{|c|c|c|c|c|c|c|c|}
\hline Site & Location & $\begin{array}{c}\text { Material } \\
\text { Dated }\end{array}$ & Affiliation & $\begin{array}{c}\text { Calibrated Date Two Sigma Ranges } \\
\text { Median Probability Date* }\end{array}$ & $\begin{array}{l}\text { Analysis } \\
\text { Number }\end{array}$ & $\begin{array}{l}\text { Conventonal } \\
\text { Date }\end{array}$ & Reference \\
\hline Icehouse Bottom & $\begin{array}{l}\text { Eastern } \\
\text { Tennessee }\end{array}$ & Kernel & $\begin{array}{l}\text { Middle } \\
\text { Woodland }\end{array}$ & $\begin{array}{l}\text { Two Sigma Ranges: Relative Area } \\
\text { [cal A.D. 25: cal A.D. 441] } 0.97313 \\
\text { [cal A.D. 484: cal A.D. 532] } 0.02687 \\
\text { Median Probability A.D. 252 }\end{array}$ & Beta-16576 & $1775 \pm 100$ & $\begin{array}{l}\text { Chapman and Crites 1987; } \\
\quad \text { Crawford et al. 1997:Table } 1\end{array}$ \\
\hline Edwin Harness & $\begin{array}{l}\text { South Central } \\
\text { Ohio }\end{array}$ & Kernel & $\begin{array}{l}\text { Middle } \\
\text { Woodland }\end{array}$ & $\begin{array}{l}\text { Two Sigma Ranges: Relative area } \\
\text { [cal A.D. 78: cal A.D. 547] } 1 . \\
\text { Median Probability A.D. } 311\end{array}$ & Beta-19291 & $1720 \pm 105$ & Crawford et al. 1997:Table 1 \\
\hline Edwin Harness & $\begin{array}{l}\text { South Central } \\
\text { Ohio }\end{array}$ & Kernel & $\begin{array}{l}\text { Middle } \\
\text { Woodland }\end{array}$ & $\begin{array}{l}\text { Two Sigma Ranges: Relative Area } \\
\text { [cal A.D. 89: cal A.D. 102] } 0.0096 \\
\text { [cal A.D. 123: cal A.D. 467] } 0.941339 \\
\text { [cal A.D. 480: cal A.D. 534] } 0.048981 \\
\text { Median Probability A.D. } 301\end{array}$ & Beta-18290 & $1730 \pm 85$ & Crawford et al. 1997:Table 1 \\
\hline Grand Banks & $\begin{array}{l}\text { Southern } \\
\text { Ontario }\end{array}$ & Kernel & $\begin{array}{l}\text { Early Late } \\
\text { Woodland }\end{array}$ & $\begin{array}{l}\text { Two Sigma Ranges: Relative Area } \\
\text { [cal A.D. 133:cal A.D. 728) } 0.982085 \\
\text { [cal A.D. 736: cal A.D. 771] } 0.017915 \\
\text { Median Probability A.D. } 530\end{array}$ & TO-5308 & $1500 \pm 150$ & Crawford et al. 1997:Table 1 \\
\hline Grand Banks & $\begin{array}{l}\text { Southern } \\
\text { Ontario }\end{array}$ & Kernel & $\begin{array}{l}\text { Early Late } \\
\text { Woodland }\end{array}$ & $\begin{array}{l}\text { Two Sigma Ranges:Relative Area } \\
\text { [cal A.D. 259: cal A.D. 285] } 0.02543 \\
\text { [cal A.D. 288: cal A.D. 292] } 0.003874 \\
\text { [cal A.D. 322: cal A.D. 648] } 0.970696 \\
\text { Median Probability A.D. } 481\end{array}$ & TO-5307 & $1570 \pm 90$ & Crawford et al. 1997:Table 1 \\
\hline Grand Banks & $\begin{array}{l}\text { Southern } \\
\text { Ontario }\end{array}$ & Cupules & $\begin{array}{l}\text { Early Late } \\
\text { Woodland }\end{array}$ & $\begin{array}{l}\text { Two Sigma Ranges: Relative Area } \\
\text { [cal A.D. 650: cal A.D. 903] 0.930775 } \\
\text { [cal A.D. 915: cal A.D. 968] } 0.069 \\
\text { Median Probability A.D. } 776\end{array}$ & TO-4586 & $1250 \pm 80$ & Crawford et al. 1997:Table 1 \\
\hline Meyer & $\begin{array}{l}\text { Southern } \\
\text { Ontario }\end{array}$ & Cupules & $\begin{array}{l}\text { Early Late } \\
\text { Woodland }\end{array}$ & $\begin{array}{l}\text { Two Sigma Ranges: Relative Area } \\
\text { [cal A.D. 607: cal A.D. } 979 \text { ] } 1 . \\
\text { Median Probability A.D. } 765\end{array}$ & TO-8150 & $1270 \pm 100$ & $\begin{array}{l}\text { Crawford and Smith } \\
\text { 2003:Table } 6.2\end{array}$ \\
\hline Forster & $\begin{array}{l}\text { Southern } \\
\text { Ontario }\end{array}$ & Cupules & $\begin{array}{l}\text { Late Late } \\
\text { Woodland }\end{array}$ & $\begin{array}{l}\text { Two Sigma Ranges: Relative Area } \\
\text { [cal A.D. 661: cal A.D. 1040] } 0.996 \\
\text { [cal A.D. 1109: cal A.D. 1116] } 0.004 \\
\text { Median Probability A.D. } 871\end{array}$ & TO-7039 & $1150 \pm 100$ & $\begin{array}{l}\text { Crawford and Smith } \\
\text { 2003:Table } 6.2\end{array}$ \\
\hline 211-1-1 & New York & Cupule & $\begin{array}{l}\text { Late Late } \\
\text { Woodland }\end{array}$ & $\begin{array}{l}\text { Two Sigma Ranges: Relative Area } \\
\text { [cal A.D. 711: cal A.D. 745] } 0.036 \\
\text { [cal A.D. 764: cal A.D. 1025] } 0.964 \\
\text { Median Probability A.D. } 897\end{array}$ & B-53452 & $1130 \pm 70$ & $\begin{array}{l}\text { Crawford and Smith } \\
\text { 2003:Table } 6.2\end{array}$ \\
\hline
\end{tabular}


These proved to be small bits of porous tissue lacking anatomical features that would clearly identify them as maize cob fragments. They included one fragment from Feature 1, which also yielded one of the original 1994-dated "cob" fragments. Based on this contextual association, that fragment was also selected for dating. All materials to be tested were photographed and submitted to the Illinois State Geological Survey for conversion to $\mathrm{CO}_{2}$ and carbon isotope assays. Gases were sent to the University of California, Irvine, for counting using their accelerated mass spectrometer.

The results of these analyses show that (1) some of the original identifications were in error, and (2) items correctly identified as maize were not Middle Woodland in age (Table 2). Of the six new samples, three — an alleged "cob" from Feature 1, a "cupule" from Feature 5, and a "kernel" fragment from Feature 5-returned $\delta^{13} \mathrm{C}$ values of $-29.5 \%$, $-24.1 \%$, and $-26.25 \%$, respectively. Identifications of the other three samples, two kernels and one cupule, were verified by carbon ratios as maize, but all three returned post-A.D. 900 dates (see Table 2).

The $\delta^{13} \mathrm{C}$ value of $-29.5 \%$ for the alleged "cob" fragment from Feature 1 is of particular interest, as one of the 1994 dates was also derived from a "cob" fragment from that feature. Although no photographs of the item dated in 1994 exist, it is likely to have been similar in appearance to the recently assayed fragment (Figure 2a). That item lacked distinctive morphological characters but did exhibit a porous texture similar to that seen in carbonized prehistoric maize cob and rachis fragments (Figure 2b). Textural similarities no doubt contributed to the original misidentification.

While the dates returned by the University of Arizona AMS laboratory and reported by Riley et al. (1994) were in keeping with a Middle Woodland association, at that time, measuring $\delta^{13} \mathrm{C}$ ratios was not standard protocol if the identifications were "confirmed" by the individuals submitting the samples, in this case researchers at the University of Illinois at Urbana-Champaign (Timothy Jull, University of Arizona AMS Laboratory, personal communication 2016). Fortunately, the very small residues from the original samples were still in curation at the University of Arizona, and the Environmental Isotope Laboratory at the university was able to run carbon ratio assays on those residues. The analysis returned $\delta^{13} \mathrm{C}$ values of $-26.00 \%$ and $-25.3 \%$, indicating that the original samples were not maize, confirming suspicions raised by the current study.

\section{Considerations for Evaluating Maize Macroremains}

Studies of ancient maize from Illinois have highlighted two important issues that must be considered when dealing with these early materials. First and foremost, it is critical that direct dates be obtained on materials to confirm antiquity (Blake 2006; Fritz 1994, 1995; Hart 2008). When assessing maize antiquity, it is no longer sufficient to rely on dates from associated organics or on the age of associated cultural material. This is particularly important for maize, but it should also apply to any unusual or exotic plant materials recovered from unexpectedly early contexts. At least within the Illinois study area, contamination of older features by materials from later occupations is common. Further, contamination occurs even in the absence of evidence for later prehistoric or historic habitation, perhaps as a function of reuse of old site areas for fields. For example, maize from the single-component early Late Woodland (Weaver phase, cal A.D. 350$650)$ Sartorius site (11HA360) in western Illinois (Fishel 2012:9) was dated to the nineteenth century (Simon 2014). This is interpreted as reflecting use of this space as a maize field during a time substantially postdating the prehistoric occupation (Simon 2014).

The second issue concerns the reliability of identifications of maize macroremains. There are some plants native to the Midwest that follow the C-4 photosynthetic pathway and that likely were consumed by humans, including pigweed (Amaranthus retroflexus) and panic grass (Panicum virgatum). However, maize, which was introduced to the area from Mesoamerica, was the most important to subsistence in the late prehistoric Midwest. Because the C-4 pathway produces plant tissues enriched with heavy carbon, carbon isotope ratio assays of tissues are a quick and easy way to confirm 
Table 2. Radiocarbon Dates and Carbon Isotope Ratios Returned on Samples from the Holding Site.

\begin{tabular}{|c|c|c|c|c|c|c|}
\hline Context & Material & $\begin{array}{l}\text { RCYPB Date } \\
\text { Returned }\end{array}$ & $\begin{array}{l}\text { Analysis } \\
\text { Number }\end{array}$ & $\begin{array}{c}\text { Calibrated Date } 2 \text { Sigma, Relative } \\
\text { Area** }\end{array}$ & & Cultural Period \\
\hline Feature $1^{1}$ & & $2077 \pm 70$ & AA 8717 & NOT MAIZE* & $-26 \%$ & $\begin{array}{l}\text { (Date is Middle } \\
\text { Woodland) }\end{array}$ \\
\hline Feature $5^{1}$ & & $2017 \pm 50$ & AA 8718 & NOT MAIZE* & $-25.3 \%$ & $\begin{array}{l}\text { (Date is Middle } \\
\text { Woodland) }\end{array}$ \\
\hline Feature $27^{2}$ & Kernel & $940 \pm 15$ & ISGS A2715 & $\begin{array}{l}\text { (1031 A.D.:1059 A.D.) } .221771 \\
\text { (1065 A.D.:1073 A.D.) } .030115 \\
\text { (1075 A.D.:1155 A.D.) } .748114 \\
\text { Median Probability } 1100 \text { A.D. }\end{array}$ & $-9.1 \%$ & Mississippian \\
\hline Feature $9^{2}$ & Kernel & $950 \pm 15$ & ISGS A2716 & $\begin{array}{l}\text { (1025 A.D.:1055 A.D.) } .273635 \\
\text { (1077 A.D.:1154 A.D.) } .726365 \\
\text { Median Probability } 1100 \text { A.D. }\end{array}$ & $-8.9 \%$ & Mississippian \\
\hline Feature $159^{2}$ & Cupule & $1070 \pm 20$ & ISGS A2714 & $\begin{array}{l}\text { (898 A.D.:920 A.D.) } .181234 \\
\text { (945 A.D.:1018 A.D.) } .818766 \\
\text { Median Probability } 982 \text { A.D. }\end{array}$ & $-9.3 \%$ & $\begin{array}{l}\text { Terminal Late Woodland } \\
\text { II }\end{array}$ \\
\hline Feature $1^{2}$ & $\begin{array}{l}\text { Designation per Riley } \\
\text { 1994: "cob" }\end{array}$ & NONE & N/A & NO DATE—NOT MAIZE & $-29.54 \%$ & N/A \\
\hline Feature $5^{2}$ & $\begin{array}{l}\text { Designation per Riley } \\
\text { 1994: "cupule" }\end{array}$ & NONE & N/A & NO DATE—NOT MAIZE & $-24.13 \%$ & N/A \\
\hline Feature 5/Midden ${ }^{2}$ & $\begin{array}{l}\text { Designation per Riley } \\
\text { 1994: "kernel" }\end{array}$ & NONE & N/A & NO DATE—NOT MAIZE & $-26.25 \%$ & N/A \\
\hline
\end{tabular}

1. Original dates returned (Riley et al. 1994).

2. New dates and isotope ratios returned, this paper.

*University of Arizona 2016

**Calibrations: Calib 7.1 http://calib.qub.ac.uk/calib/calib.html, accessed May 20, 2016; Stuiver and Reimer 2016. 

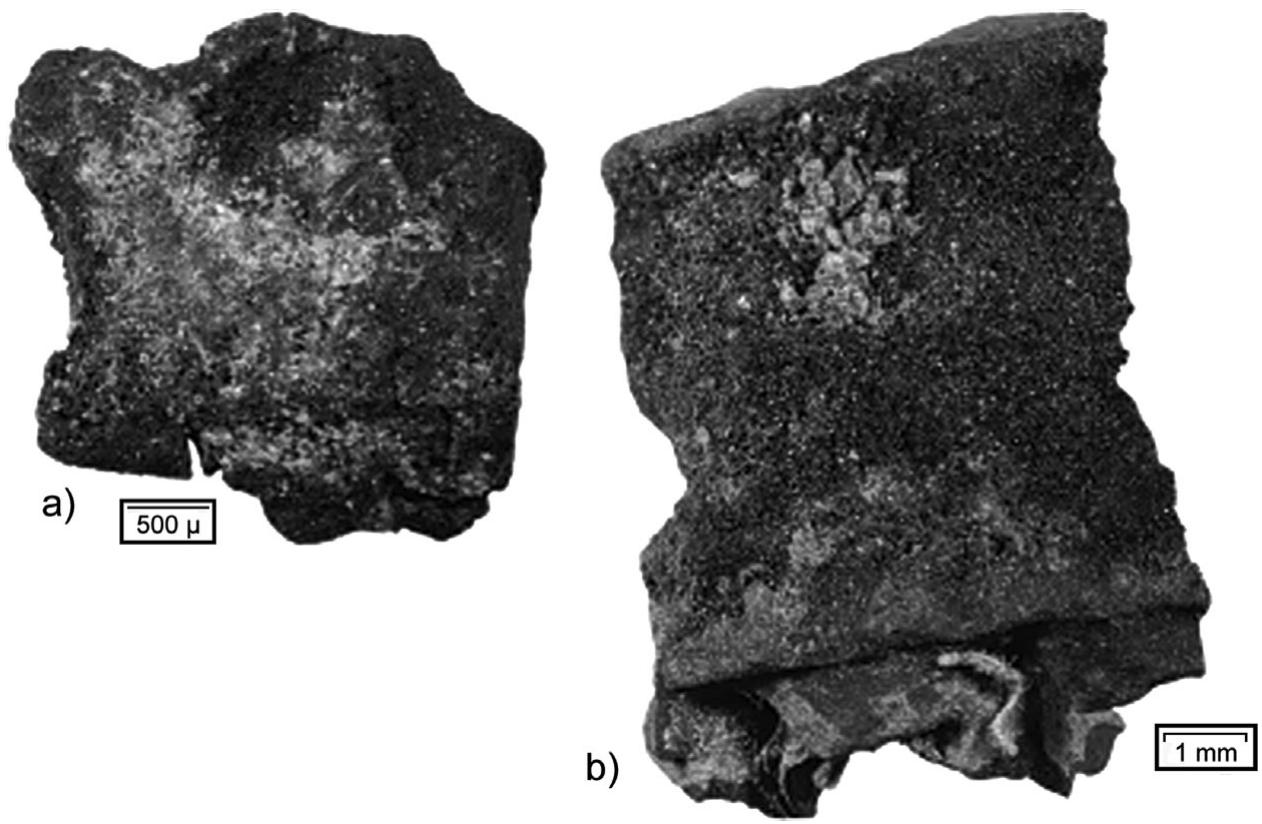

Figure 2. (a) Fragment of item originally identified as a "maize cob," and which returned a non-maize carbon isotope value, showing characteristic texture; (b) interior of a rachis fragment from the late prehistoric Palos site, 11CK26, in Illinois. Note similarities in texture despite large differences in scale.

that archaeological materials being evaluated are truly maize. Studies to date have shown that identifications by experienced researchers are usually accurate (Simon 2014), but, as exemplified by the Holding site samples, there are occasions when this does not hold true. Even for small fragments, technologies are now such that carbon isotope ratios can be readily assayed as standard protocol. These assays can be inexpensively obtained using stable isotope ratio mass spectrometry (SIRMS), confirming identifications before radiometric dates are even run. In the absence of carbon isotope confirmation, particularly for problematic materials or in situations where the material is from an unusually early context, it is reasonable to question dates on materials reported as "maize."

\section{Revising and Reconsidering the Model for Maize Use in Illinois}

The results of the Holding site maize studies effectively rewrite the history for maize use in the American Bottom and have implications for understanding its history over the broader Midwest and even the greater Eastern Woodlands. Simply put, the Holding site maize no longer stands as the oldest directly dated maize in the midwestern United States. The most recent set of dates and carbon isotope assessments, and carbon isotope values obtained on residues submitted for dating over two decades ago, show that some of the material was originally misidentified and that those materials that are maize date to almost one millennium later than the Middle Woodland period.

In Illinois, the oldest directly dated maize reported thus far is from the Edgar Hoener site. This fragment dated to between about cal A.D. 700 and 750 and provided a $\delta^{13} \mathrm{C}$ of $-10.1 \%$ (Simon 2014:Table 3). It is not unreasonable to assume that maize was occasionally present by ca. A.D. 750 in the Midwest. The question becomes how to interpret this presence. For example, it may reflect early efforts at maize cultivation or the acquisition of an unusual item through trade. Regardless, its near absence from the massive archaeobotanical database that has accumulated in Illinois over the past several 
decades (e.g., Asch and Asch 1985; Johannessen 1984, 2000, 2014; Simon and Parker 2006) indicates that if maize was occasionally obtained it was inconsequential, even as an occasional garden plant, until about A.D. 900, when its use literally exploded. This is a subtle, but important, shift in our model. Although technically qualifying as "maize cultivation," meaning that it reflects the planting and care of a plant, this recovery should not be interpreted as indicating a widespread practice at this early date, nor are there any implications of continuity within the Illinois study region. "Cultivation" may well have been a one-and-done activity. It is also important to consider how the technology of maize cultivation fits our understanding of existing prehistoric subsistence technologies (Hart and Lovis 2013; Reber 2006; Scarry 2006; Smith and Cowan 2003). Technologies for native-plant cultivation and maize cultivation differ and may not have been compatible under some settlement systems (Smith and Cowan 2003).

\section{The Maize Paradox}

The history of maize in the Eastern Woodlands remains a subject of paramount interest and paradox. Among the most interesting is the contrast between dated macroremains and dates obtained on residues containing maize microremains. AMS dates on maize from sites in western Illinois and eastern Kansas indicate that, with the exception of the Edgar Hoener maize discussed above, those materials, once thought to date to the Middle and Late Woodland periods, are actually much younger than the contexts of recovery would suggest (Adair 2012; Adair and Drass 2011; Conard et al. 1984; Simon 2014). In Illinois, these results are strongly supported by recent skeletal isotope analyses (Emerson et al. 2015).

The only remaining macroremains directly dated to the Middle Woodland period are from the Icehouse Bottom site in Tennessee and the Edwin Harness site in Ohio (see Table 1; Chapman and Crites 1987). Somewhat younger are maize macroremains from the Grand Banks and Meyer sites, in southern Ontario, which have been dated to the Late Woodland period using AMS (see Table 1 for calibrated dates on these sites; Crawford and Smith 2003; Crawford et al. 1997). However, as was true for the original Holding site materials, AMS dates for these samples were run at a time when obtaining $\delta^{13} \mathrm{C}$ assays was not standard protocol, so all are unfortunately lacking confirmation of identification.

On the other hand, maize microremains, whether phytoliths or starch grains, have been identified in pot residues dating to as early as 200-300 B.C. in New York State and to the first centuries A.D. from sites in Michigan, New York, and Ontario (Hart 2008; Hart et al. 2007:Table 6; Hart and Lovis 2013; Hart et al. 2003; Raviele 2010; St-Pierre and Thompson 2015; Thompson et al. 2004). Consequently, as dates on maize macroremains in the interior Midwest push our temporal scale for use forward in time, residue analyses of phytoliths and starches from ceramics recovered from the Great Lakes region extend its use back in time.

Among the many questions raised by these seemingly conflicting data sets are those concerning routes of transmission; that is, how did corn get from Mesoamerica or the southwestern United States to the northeastern United States by 200-300 B.C.? Assuming a transmission route through the central Midwest, whether overland or via the Mississippi River and its tributaries, why and how did it leave almost no evidence for its passage? This is particularly puzzling if, as suggested for what is now New York State, the evolutionary process that ultimately resulted in the genetically distinct Northern Flint maize variety (Doebley et al. 1986) was initiated by 300 B.C. and proceeded over the centuries immediately following (Hart and Lovis 2013:200). Seed stock would have had to have been repeatedly introduced over those ensuing centuries to provide a viable maize crop that would enable the whole evolutionary process. The transmission route or routes for maize into the eastern United States remain unclear, although the Illinois and Kansas data cited here suggest that it was not through the central Mississippi River valley via either the Missouri River or an overland route. Nor do we have evidence for its early passage via the lower Mississippi River (cf. Fritz and Kidder 1993; Kidder 1992; Wilson and Perttula 2013). Recent research has suggested a more northerly transmission route for domesticated 
bean into the Northeast, albeit at a much later date than maize (Monaghan et al. 2014). Again, early records for maize across the northern Great Plains, Minnesota, and Wisconsin are absent, although maize starch was identified in vessel residues from Michigan (Raviele 2010).

As Hart (2014:170) has noted, models and hypotheses are strengthened when supported by multiple lines of data. We plan to initiate parallel analyses of residues from Late Woodland ceramics to determine whether maize phytoliths are present and to help clarify our understanding of maize history in our study region. At the same time, it is also imperative that those working in other areas increase their attempts to identify macroremains that corroborate the microremains record. Thus far, the flotation database from the northeastern United States and extending into eastern Pennsylvania has yet to include any direct dates on maize from that region predating ca. A.D. 850 (Asch-Sidell 2002; Cassedy and Webb 1999; Chilton 2006; Hart 2008; Hart and Lovis 2013; McConaughy 2008). While it is not unreasonable to assume that histories of maize will vary among geographic regions (e.g., Staller et al. 2006), this paradox indicates there is still much to learn about those histories.

Acknowledgments. I thank Dr. Thomas Emerson and Dr. Kristin Hedman, my colleagues at the Illinois State Archaeological Survey, for their exemplary editing prowess, as well as their support and encouragement. I also want to thank Kathryn Parker and Sissel Johannessen for their pioneering work in American Bottom archaeobotany and for recognizing that we can and should reevaluate our own research and theories. Thank you to the anonymous reviewers of this paper. Your comments and suggestions helped considerably in fleshing out details and clarifying the text. Mary Lou Wilshaw-Watts provided technical editorial assistance. Michael Farkas, at the Illinois State Archaeological Survey, prepared Figure 1, which is used with permission of the Illinois State Archaeological Survey. Eider Etxebarria Zuluaga, University of Illinois Department of Spanish, provided the Spanish abstract translation. This research was conducted and funded by the Illinois State Archaeological Survey, Prairie Research Institute, at the University of Illinois, at Urbana-Champaign. Funding for the original Holding site excavations was provided by the Illinois Department of Transportation, then under the direction of Dr. John Walthall. The author accepts full responsibility for the accuracy of the material presented and for any errors in that presentation.

Data Availability Statement. The remaining Holding site maize samples are curated at the Illinois State Archaeological Survey, Champaign. The data records collected from the analyses presented here are also available from the Illinois State Archaeological Survey. These data records are available upon request from the author.

\section{References Cited}

Adair, Mary J.

2012 Refining Plains Woodland Chronology. Plains Anthropologist 57:183-228.

Adair, Mary J., and Richard D. Drass

2011 Patterns of Plant Use in the Prehistoric Central and Southern Plains. In The Subsistence Economies of Indigenous North American Societies, edited by Bruce D. Smith, pp. 307-352. Smithsonian Institution, Washington, D.C.

Asch, David L., and Nancy B. Asch

1985 Prehistoric Plant Cultivation in West Central Illinois. In Prehistoric Food Production in North America, edited by Richard I. Ford, pp. 149-203. University of Michigan Anthropological Papers No. 75. Museum of Anthropology, University of Michigan, Ann Arbor.

Asch-Sidell, Nancy

2002 Paleoethnobotanical Indicators of Subsistence and Settlement Change in the Northeast. In Northeast Subsistence-Settlement Change A.D. 700-1300, edited by John P. Hart and Christina B. Reith, pp. 241-263. New York State Museum Bulletin 496, Albany.

Blake, Michael

2006 Dating the Initial Spread of Zea mays. In Histories of Maize: Multidisciplinary Approaches to the Prehistory, Linguistics, Biogeography, Domestication, and Evolution of Maize, edited by John E. Staller, Robert H. Tykot, and Bruce F. Benz, pp. 55-72. Academic Press, Burlington, Massachusetts.

Boyd, Mathew, and Clarence Surette

2010 Northernmost Pre-Contact Maize in North America. American Antiquity 75:117-133.

Boyd, Mathew, Tamara Varney, Clarence Surette, and Jennifer Surette

2008 Reassessing the Northern Limit of Maize Consumption in North America: Stable Isotope, Plant Microfossil, and Trace Element Content of Carbonized Food Residue. Journal of Archaeological Science 35:25452556.

Cassedy, Daniel, and Paul Webb

1999 New Data on the Chronology of Maize Horticulture in Eastern New Yorkand Southern New England. In Current Northeast Paleoethnobotany, edited by John P. Hart, pp. 85-99. New York State Museum Bulletin No. 494, Albany.

Chapman, Jefferson, and Gary D. Crites

1987 Evidence for Early Maize (Zea mays) from the Icehouse Bottom Site, Tennessee. American Antiquity 52:352-354.

Chilton, Elizabeth

2006 The Origin and Spread of Maize (Zea mays) in New England. In Histories of Maize: Multidisciplinary Approaches to the Prehistory, Linguistics, Biogeography, Domestication, and Evolution of Maize, edited by John E. Staller, Robert H. Tykot, and Bruce F. Benz, pp. 539-547. Academic Press, Burlington, Massachusetts.

Conard, Nicholas, David L. Asch, Nancy B. Asch, David Elmore, Harry Grove, Meyer Rubin, James A. Brown, Michael D. Wiant, and Thomas G. Cook 
1984 Accelerator Radiocarbon Dating of Evidence for Prehistoric Horticulture in Illinois. Nature 308:443446.

Crawford, Gary W., Della Saunders, and David G. Smith

2006 Pre-Contact Maize from Ontario, Canada: Context, Chronology, Variation, and Plant Association. In The Histories of Maize: Multidisciplinary Approaches to the Prehistory, Linguistics, Biogeography, Domestication and Evolution of Maize, edited by John E. Staller, Robert H. Tykot and Bruce F. Benz, pp. 549-559. Academic Press Burlington, Massachusetts.

Crawford, Gary W., and David G. Smith

2003 Paleoethnobotany in the Northeast. In People and Plants in Ancient Eastern North America, edited by Paul E. Minnis, pp. 172-257. Smithsonian Books, Washington, D.C.

Crawford, Gary W., David G. Smith, and Vandy E. Bowyer 1997 Dating the Entry of Corn (Zea mays) into the Lower Great Lakes Region. American Antiquity 62: 112-119.

Doebley, John F., Major M. Goodman, and Charles W. Stuber 1986 Exceptional Genetic Divergence of Northern Flint Corn. American Journal of Botany 73(1):64-69.

Emerson, Thomas E., Kristin M. Hedman, and Mary L. Simon

2015 Cahokia and Corn: Multidisciplinary Research on the Timing and Intensity of Maize Consumption in the American Bottom. Paper presented at the 72nd Annual Southeast Archaeological Conference, Nashville, Tennessee.

Fishel, Richard L.

2012 Weaver Overview. In Archaeological Investigations at Sartorious and Sartorial Splendor: Two Weaver Sites in the LaMoine Valley Uplands of Hancock County, edited by Richard L. Fishel, pp. 9-10. Illinois State Archaeological Survey, Technical Report 132, University of Illinois, Urbana-Champaign.

Fortier, Andrew C., Thomas O. Maher, Joyce A. Williams, Michael C. Meinkoth, Kathryn E. Parker, and Lucretia S. Kelly

1989 The Holding Site: A Hopewell Community in the American Bottom. American Bottom Archaeology FAI270 Site Reports Vol. 19. University of Illinois Press, Urbana.

Fritz, Gayle

1992 "Newer," "Better" Maize and the Mississippian Emergence: A Critique of Prime Mover Explanations. In Late Prehistoric Agriculture: Observations from the Midwest, edited by William I. Woods, pp. 19-43. Illinois Historic Preservation Agency, Springfield.

1994 Are the First American Farmers Getting Younger? Current Anthropology 35:305-309.

1995 New Dates and Data on Early Agriculture: The Legacy of Complex Hunter-Gatherers. Annals of the Missouri Botanical Garden 82:3-15.

2000 Levels of Native Biodiversity in Eastern North America. In Biodiversity and Native America, edited by Paul E. Minnis and William J. Elisens, pp. 223-247. University of Oklahoma Press, Norman.

Fritz, Gayle J., and Tristram R. Kidder

1993 Recent Investigations into Prehistoric Agriculture in the Lower Mississippi Valley. Southeastern Archaeology 12:1-14.

Hart, John P

2008 Evolving the Three Sisters: The Changing Histories of Maize, Bean, and Squash in New York and the Greater
Northeast. In Current Northeast Paleoethnobotany II, edited by John P. Hart, pp. 87-99. New York State Museum Bulletin Series No. 512, Albany.

2014 A Critical Assessment of Current Approaches to Investigations of the Timing, Rate, and Adoption Trajectories of Domesticates in the Midwest and Great Lakes. In Reassessing the Timing, Rate, and Adoption Trajectories of Domesticate Use in the Midwest and Great Lakes, edited by Maria E. Raviele and William A. Lovis, Midwest Archaeological Conference Occasional Papers No. 1:161-174, Champaign, Illinois.

Hart, John P., Hetty Jo Brumbach, and Robert Lusteck

2007 Extending the Phytolith Evidence for Early Maize (Zea mays ssp. mays) and Squash (Cucurbita sp.) in Central New York. American Antiquity 72:563-583.

Hart, John P., and William A. Lovis

2013 Reevaluating What We Know about the Histories of Maize in Northeastern North America: A Review of Current Evidence. Journal of Archaeological Research 21:175-216.

Hart, John P., Richard G. Thompson, and Hetty Jo Brumbach 2003 Phytolith Evidence for Early Maize (Zea mays) in the Northern Finger Lakes Region of New York. American Antiquity 68:619-640.

Hastorf, Christine A., and Sissel Johannessen

1994 Becoming Corn Eaters in Prehistoric America. In Corn and Culture in the Prehistoric New World, edited by Sissel Johannessen and Christine A. Hastorf, pp. 427-443. Westview, Boulder, Colorado.

Johannessen, Sissel

1984 Paleoethnobotany. In American Bottom Archaeology: A Summary of the FAI-270 Project Contribution to the Culture History of the Mississippi River Valley, edited by Charles J. Bareis and James W. Porter, pp. 197-214. University of Illinois Press, Urbana.

1993 Farmers of the Late Woodland. In Foraging and Farming in the Eastern Woodlands, edited by C. Margaret Scarry, pp. 57-77. University Press of Florida, Gainesville.

Kidder, Tristram R.

1992 Timing and Consequences of the Introduction of Maize Agriculture in the Lower Mississippi Valley. North American Archaeologist 13:15-41.

Lopinot, Neal H.

1994 A New Crop of Data on the Cahokian Polity. In Agriculture Origins and Development in the Midcontinent, edited by William Green, pp. 127-153. Office of the State Archaeologist, University of Iowa, Iowa City.

1997 Cahokian Food Production Reconsidered. In Cahokia: Domination and Ideology in the Mississippian World, edited by Timothy R. Pauketat and Thomas E. Emerson, pp. 52-68. University of Nebraska Press, Lincoln.

McConaughy, Mark A.

2008 Current Issues in Paleoethnobotanical Research from Pennsylvania and Vicinity. In Current Northeast Paleoethnobotany II, edited by John P. Hart, pp. 927. New York State Museum Bulletin Series No. 512, Albany.

Monaghan, G. William, Timothy M. Schilling, and Kathryn E. Parker

2014 The Age and Distribution of Domesticated Beans (Phaseolus vulgaris) in Eastern North America: Implications for Agricultural Practices and Group Interactions. In Reassessing the Timing, Rate, and Adoption 
Trajectories of Domesticate Use in the Midwest and Great Lakes, edited by Maria E. Raviele and William A. Lovis, Midwest Archaeological Conference Occasional Papers No. 1:33-51, Champaign, Illinois.

Parker, Kathryn E.

1989 Archaeobotanical Assemblage. In The Holding Site: A Hopewell Community in the American Bottom, edited by Andrew C. Fortier, Thomas O. Maher, Joyce A. Williams, Michael C. Meinkoth, Kathryn E. Parker, and Lucretia S. Kelly, pp. 429-464. American Bottom Archaeology FAI-270 Site Reports Vol. 19. University of Illinois Press, Urbana.

Raviele, Maria E.

2010 Assessing Archaeological Cooking Residues: Evaluation of Maize Phytolith Taphonomy and Density through Experimental Residue Analysis. Unpublished $\mathrm{Ph}$. D. dissertation, Department of Anthropology, Michigan State University, East Lansing.

Reber, Eleanora A.

2006 A Hard Row to Hoe: Changing Maize Use in the American Bottom and Surrounding Areas. In Histories of Maize: Multidisciplinary Approaches to the Prehistory, Linguistics, Biogeography, Domestication, and Evolution of Maize, edited by John E. Staller, Robert H. Tykot, and Bruce F. Benz, pp. 235-248. Academic Press, Burlington, Massachusetts.

Riley, Thomas J., Gregory R. Walz, Charles J. Bareis, Andrew C. Fortier, and Kathryn E. Parker

1994 Accelerator Mass Spectrometry (AMS) Dates Confirm Early Zea mays in the Mississippi River Valley. American Antiquity 59:490-498.

Scarry, C. Margaret

2006 Crop Husbandry Practices in North America's Eastern Woodlands. In Case Studies in Environmental Archaeology, 2nd ed., edited by Elizabeth J. Reitz, C. Margaret Scarry, and Sylvia J. Scudder, pp. 391-404. Springer, New York

Simon, Mary L.

2000 Regional Variations in Plant Use Strategies in the Midwest during the Late Woodland. In Late Woodland Societies: Tradition and Transformation across the Midcontinent, edited by Thomas E. Emerson, Dale L. McElrath, and Andrew C. Fortier, pp. 37-75. University of Nebraska Press, Lincoln.

2014 Reevaluating the Introduction of Maize into the American Bottom and Western Illinois. In Reassessing the Timing, Rate, and Adoption Trajectories of Domesticate Use in the Midwest and Great Lakes, edited by Maria E. Raviele and William A. Lovis, Midwest Archaeological Conference Occasional Papers No. 1:97-134, Champaign, Illinois.

Simon, Mary, and Kathryn Parker

2006 Prehistoric Plant Use in the American Bottom: New Thoughts and Interpretations. Southeastern Archaeology $25: 170-211$.
Smith, Bruce D., and C. Wesley Cowan

2003 Domesticated Crop Plants and the Evolution of Food Producing Economies in Eastern North America. In People and Plants in Ancient Eastern North America, edited Paul E. Minnis, pp. 105-125. Smithsonian Institution Press, Washington, D.C.

Staller, John, Robert Tykott, and Brice Benz (editors)

2006 The Histories of Maize: Multidisciplinary Approaches to the Prehistory, Linguistics, Biogeography, Domestication and Evolution of Maize. Academic Press, Burlington, Massachusetts.

St-Pierre, Christian Gates, and Robert G. Thompson

2015 Phytolith Evidence for the Early Presence of Maize in Southern Quebec. American Antiquity 80:408-415.

Stuiver, Minze, and Paula Reimer

2016 CALIB REV 7.1.0 Radiocarbon Calibration Program. Electronic document, http://calib.qub.ac.uk/ calib/.html, accessed May 20, 2016.

Thompson, Robert G., John P. Hart, Hetty Jo Brumbach, and Robert Lusteck

2004 Phytolith Evidence for Twentieth Century B.P. Maize in Northern Iroquoia. Northeast Anthropology 68:25-40.

VanDerwarker, Amber M., Gregory D. Wilson, and Dana M. Bardolph

2013 Maize Adoption and Intensification in the Central Illinois River Valley: An Analysis of the Archaeobotanical Data from the Late Woodland to Early Mississippian Periods (A.D. 600-1200). Southeastern Archaeology 32:147-168.

Wagner, Gail E.

1994 Corn and Eastern Woodland Prehistory. In Corn and Culture in the Prehistoric New World, edited by Christine Hastorf and Sissel Johannessen, pp. 335-436. Westview, Boulder, Colorado.

Wilson, Diane, and Timothy K. Perttula

2013 Reconstructing the Paleodiet of the Caddo through Stable Isotopes. American Antiquity 78:702-723.

Wright, Patti J., and Christopher A. Shaffer

2014 Crop Selection: Perspectives from the Lower Missouri River Basin. In Reassessing the Timing, Rate, and Adoption Trajectories of Domesticate Use in the Midwest and Great Lakes, edited by Maria E. Raviele and William A. Lovis, Midwest Archaeological Conference Occasional Papers No. 1:73-96, Champaign, Illinois.

Wymer, Dee Anne

1993 Cultural Change and Subsistence: The Middle and Late Woodland Transition in the Mid-Ohio Valley. In Foraging and Farming in the Eastern Woodlands, edited by C. Margaret Scarry, pp. 138-156. University Press of Florida, Gainesville.

Submitted June 30, 2016; Revised August 25, 2016 Accepted August 26, 2016 